\title{
Educative Power and the Respectful Curricular Inclusion of Aboriginal and Torres Strait Islander Music
}

\author{
Michael Webb and Clint Bracknell
}

\begin{abstract}
This chapter argues for the full, respectful curricular inclusion of Aboriginal and Torres Strait Islander music in order to promote a more balanced and equitable social and cultural vision of the nation-state in Australian schools. It challenges views that claim Indigenous cultures have been irretrievably lost or are doomed to extinction, as well as the fixation on musical authenticity. We propose that the gradual broadening of Indigenous musical expressions over time and the musical renaissance of the new millennium have created an unprecedented opportunity for current music educators to experience the educative power of Aboriginal and Torres Strait Islander music. This means that culturally nonexposed music teachers can employ familiar musical-technical approaches to the music even as they begin to more fully investigate the music's cultural-contextual meanings. The chapter considers issues that impinge on the music's educative power, especially those relating to its definition, its intended audiences, and pedagogies. It aims to help clear the way for the classroom to become an environment in which students can sense the depth and vitality of contemporary Australian Indigenous music.
\end{abstract}

Keywords Indigenous music - Aboriginal and Torres Strait Islander music · Partnership pedagogy $\cdot$ Educative power

\footnotetext{
This essay is based on the authors' experience in collaborating in the design and delivery of a tertiary course on Aboriginal and Torres Strait Islander music for pre-service music educators at the Sydney Conservatorium of Music (The University of Sydney), 2016-2018. Thomas Fienberg, whose work is mentioned in the chapter, taught the unit in 2019.
}

M. Webb (ه)

Sydney Conservatorium of Music, The University of Sydney, Camperdown, NSW, Australia e-mail: michael.webb@sydney.edu.au

C. Bracknell

Kurongkurl Katitjin Centre for Indigenous Australian Education \& Research, Western Australian Academy of Performing Arts - WAAPA, Edith Cowan University, Joondalup, WA, Australia

e-mail: c.bracknell@ecu.edu.au

A. A. Kallio et al. (eds.), The Politics of Diversity in Music Education,

Landscapes: the Arts, Aesthetics, and Education 29,

https://doi.org/10.1007/978-3-030-65617-1_6 


\section{Introduction}

In his memorable Redfern Park speech, to mark 1993 as the United Nations International Year for the World's Indigenous People, Australian Prime Minister Paul Keating (1992) acknowledged that colonists "smashed the traditional way of life" of Aboriginal and Torres Strait Islander peoples. The British colonists' assumption of racial superiority drove their relentless assault on established Indigenous customs that had been practiced over vast expanses of territory and time. The rapid and prolonged endangerment of numerous unique languages and performance traditions that followed was but one result of a denial of Indigenous sovereignty. A politics of exclusion developed around two of the settler colonists' founding ideologies. First, "terra nullius", the doctrine that no one was here when the settler colonists arrived ensured that the autochthonous residents and their cultural expressions were pushed to the margins of the national story. Second, the notion of the "noble savage", meant that Indigenous music created as a result of European colonization was for decades overlooked on the grounds that it was derivative or inauthentic (Guy 2015), just as Indigenous peoples with a non-Indigenous parent were denigrated as 'half-caste', a supposed "contaminated version of a pristine and primitive race" (Rowse 2017, p. 4).

This chapter challenges the long-term lack of engagement between Australia's mainstream music education system and Aboriginal and Torres Strait Islander musical cultures. Such persistent indifference and inertia in educational policy and practice may be seen to perpetuate colonial logics and counter curricular ideals of cultural respect and inclusion. For purposes of remediation, we trace this history of educational neglect in an attempt to clear a path for corrective action on the grounds that Australia's Indigenous music possesses "educative power" (Boyea 1999, p. 32). By this, following Boyea (1999), we argue that Aboriginal and Torres Strait Islander music can be "looked at from within the culture as part of the culture and from outside the culture as music only, music in itself. It can be examined for its meanings or simply for its musical traits" (p. 32). As Boyea elaborates, the music "can be looked at functionally or aesthetically, spiritually or secularly, as an object for observation and a process to be performed" (p. 32). This frees the non-Indigenous "nonexposed" music teacher (Boyea 1999, p. 36), that is, the teacher who has little experience of Australian Indigenous culture, from the pressure of having to authentically present the music "within a cultural context" as the syllabus support document requires (Board of Studies NSW 2004, p. 37). This, by the way, is a condition that is placed on no other music form, style or genre.

We begin by confronting the deficit discourse that has been so detrimental to Aboriginal and Torres Strait Islanders and their cultural expressions and remind educators that Indigenous Australians, particularly through music and performance, have "adapted and developed new ways of communicating the strength and histories of their cultures" (Casey 2012, p. 1). We also discuss the epistemological disjuncture 
that impeded more widespread curricular inclusion of Aboriginal and Torres Strait Islander music by educationists until almost the end of the twentieth century. We devote the remaining space to an exploration of issues that impinge on the music's educative power, especially those relating to definitions, the music's intended audiences and pedagogies.

\section{Traditions and Curricula in Transition}

The most detailed and sustained historical account to date of the music and dance of an Aboriginal nation is Anna Haebich's Dancing in the Shadows (2018), which demonstrates how the Nyungar people of Western Australia have relied upon performance culture "to survive" the catastrophic impact of colonization (p. 1). Haebich (2018) challenges the fallacy that Indigenous Australians "lost" their culture, which, she writes, "suggests a deliberate ignorance and forgetting on the part of settler colonists that validated the many cruelties and injustices of colonization" (p. 3). Related to this is what Jim Wafer (2017) terms the "doomed cosmology" theory, which maintains that "even if Aboriginal people have, against all odds, managed to survive, at least their cosmology is doomed to extinction, as they come to terms with the consequences of colonial history", another idea that has proven to be false (p. 5). Music educationists have much to learn from studies such as Dancing in the Shadows, which trace and draw out continuities - and, of course, differences - between past and present expressive performance practices.

As Ottosson (2015) explains, "[p]rior to the 1960s, Indigenous Australian expressive cultural forms were, in the main, categorized and evaluated by criteria for 'primitive art', and the lesser the 'contamination' by European contact, the higher their 'authentic' value" (p. 7). For example, in the early 1960s, Aboriginal performers from Bathurst Island and Yirrkala became involved with the Elizabethan Theatre Trust in the creation of "new dynamic performances" that took their music and dance traditions to enthusiastic audiences in Melbourne and Sydney (Harris 2017, n.p.). Such interest was based on particular assumptions about art and aesthetics that arose from an epistemology that was fundamentally foreign to Indigenous culture. One newspaper review of the work signalled at least a faint recognition of the need to engage at a deeper level with Aboriginal cosmological foundations: "Most of us have great goodwill towards Aborigines and their culture, without having more than a superficial knowledge of their art [...] This remarkable stage show is not to be missed" (Giese n.d.). At the same time, "non-Indigenous Australian composers and choreographers were creating hybrid works that drew on barely understood Aboriginal story, music, and dance traditions" (Harris 2017, n.p.). For the last decades of the twentieth century, works by composers such as John Antill, Margaret Sutherland, George Dreyfus, Peter Sculthorpe and Sarah Hopkins 
and a limited selection of folk and rock songs shaped secondary students' understanding of Aboriginal musical ideas. ${ }^{1}$

By the middle of the twentieth century, ethnomusicologists were studying Aboriginal music and attempted to understand it on its own terms (Ellis 1984). As Catherine Ellis stated, "many of the values we accept as 'normal' in music, products of our own middle-class culture, are seen by others as racist and elitist" (Ellis 1974, p. 25). Ellis recognized a great need for a bridge between the expressive cultural worlds of Indigenous and non-Indigenous Australians. With Lila Rankine, she established the Centre for Aboriginal Studies in Music (CASM) at the University of Adelaide in 1972, where Aboriginal and Western ways of learning were merged to form a bi-musical pedagogy. ${ }^{2}$ Nevertheless, from the late $1960 \mathrm{~s}$, even as attitudes, policies and practices that largely excluded Indigenous people from public life were being challenged, "monocultural understandings" that were "underpinned by specific notions of 'traditional' and 'authenticity"' became entrenched (Ottosson 2015, p. 6). During this same period, pioneering groundwork for a broader public awareness of musical changes that were underway was being undertaken by prominent Indigenous musicians including Jimmy Little (Yorta Yorta), Dulcie Pitt (whose stage name was Georgia Lee) (Torres Strait Islander) and Vic Simms (Bidjigal). Songmen such as the Yankunytjatjara songwriter Bob Randall, who composed the country style lament "My Brown Skin Baby" in 1964, and Gurnu musician Dougie Young, who around 1963 composed "Land Where the Crow Flies Backwards", began to sing of their experiences of deep loss under the colonial regime.

In the 1980s, scholars issued a call to mainstream music educators to teach Aboriginal and Torres Strait Islander music (Moyle 1981; Kartomi 1988), and some even offered model teaching approaches. For example, by 1980 Alice Moyle had created an extensive educational kit for primary school teachers, but all attempts to have it published were unsuccessful until 1991. Moyle (2019) wished to "develop understanding of the importance of music and dance in the culture that, traditionally, has no writing, and to foster recognition of regional differences in Aboriginal songs and dance" (p. 25). She proposed well-intended projects such as "class-created corroborees" (Moyle 1981, p. 19), which arguably perpetuated a distorted view of the traditions they set out to promote. For various reasons, teachers were halting in their response to such initiatives, and the majority continued to exclude Aboriginal and Torres Strait Islander music from their teaching repertoires.

As an overt politics of multiculturalism gained momentum in Australia, ${ }^{3}$ non-Western music was validated in the syllabus of at least one state in the early

\footnotetext{
${ }^{1}$ For example, "Aborigine" by Gary Shearston (from the 1974 album Dingo), "Solid Rock" released in 1982 by Shane Howard's band Goanna and "Blackfella/Whitefella" by Neil Murray and George Rrurrambu of Warumpi Band, released in 1985. This quickly began to change in the mid-1980s as the discussion of pop, country, rock and reggae developments below indicates. On Australian pop music and its appropriation of Aboriginal music from the 1950s to the 1970s, see Casey (2018).

${ }^{2}$ For subsequent innovations see Chadwick and Rrurrambu (2004).

${ }^{3}$ For musical manifestations of this development, see Smith (2009).
} 
1980s (Secondary Schools Board 1983, 8). At the same time, the exclusion of Aboriginal and Torres Strait Islander music continued. Compounding this paradox, in the lead up to the implementation of multiculturalist doctrines, "coincidental with assimilation polices that sought to destroy Aboriginal identity, a growing interest in Aboriginal art and culture captured the interest of Australians at large" (Kleinert 2010, pp. 176-177).

From 1980, Indigenous musicians had adopted rock and reggae to explore themes relating to the impact of settler colonialism. Marcus Breen (1989/2007) notes that such music "was a political statement that laid claim to a missing history" (p. xii). Its sound was a "bricolage of new and emerging expressions of identity that took tribal music, as well as Jimmy Little and rock and roll and cranked it up into a mishmash of cultural empowerment" (p. xi). The band No Fixed Address, formed by students at CASM in 1979, fashioned a sound "that has since defined popular Indigenous music in the country", which, wrote Brent Clough (2012), is "an assemblage of roots reggae, ska, country, rock 'n' roll and now hip-hop - allied to the proclamation of contemporary black identity" (p. 269).

The emergence of the academic field of popular music studies, the reverberations of which began to be felt in school music education in Great Britain and Australia in the 1980s, led educationists to envision the instructional benefits of the newer music forms:

The incorporation of Australian Indigenous popular music in school curricula may be viewed as a means to cultural tolerance, as a role model for Indigenous community members, as a source of musical knowledge, as current social comment or as emblematic of cultural intricacies [...] Aligned with the immediacy of student youth, Australian Indigenous popular music may then prove a potent mix essential to the ongoing process of developing an Australian musical and cultural identity. (Wemyss 1999, p. 36)

The positive reception nationally of the Arnhem Land, Northern Territory band, and Yothu Yindi, whose music appealed to mainstream music educators seeking ways to bring Aboriginal music into their classroom, promised to advance such agendas. The band's success coincided with the rise of the Internet; its website went live in 1995 and expanded the reach of the music, including into educational settings (Neuenfeldt 1997). For lead singer Mandawuy Yunupingu, Yothu Yindi's early 1990s breakout hit, Treaty, meant that:

we were able to take our music [...] to the world. But what 'Treaty' caused here, back in Australia, was the young people, black and white, of different nationalities, understanding our music - Aboriginal music, language, the thinking. When we went out and faced the world, the world accepted our music. ${ }^{4}$

The group included Aboriginal and non-Aboriginal members, and its songs combined local language songs with rock and dance elements; thus it modelled a new way to express cultural complementarity, that is, diverse components all equally necessary to music's impact. Aaron Corn calls the band's song, Tribal Voice a "tour

\footnotetext{
${ }^{4}$ Mandawuy Yunupingu from an interview by George Negus on ABC TV, 8 July 2004, quoted on the ArtsEdge website: http://www.artsedge.dca.wa.gov.au/resources/Pages/Music.aspx.
} 
de force [that ...] set forth a vision for an Australia in which Indigenous peoples can live in harmony and mutual respect with their fellow citizens, while continuing to practice sacred laws and care for country in their traditions of their ancestors" (Corn 2017, n.p.).

Although Aboriginal and Torres Strait Island music began to be included in school music offerings with greater enthusiasm after Yothu Yindi, it was still treated as Other. Yothu Yindi was primarily considered a (Yolngu) Aboriginal band - it certainly highlighted its Aboriginality - but it was heard predominantly through a world music filter. Yothu Yindi's music tended to be exoticized, and the contributions of the band's white musicians as well as the elements of African diasporic blackness in their sound were downplayed or ignored, and for the most part, so were the subtler political messages of their songs (see Taylor 2007, pp. 156-159).

The new millennium witnessed an outpouring of creative musical expressions by Indigenous musicians, following examples set in the previous two decades by Warumpi Band, Coloured Stone, Yothu Yindi, Archie Roach and Ruby Hunter, Christine Anu, Troy Cassar-Daley and many others. This gained added impetus following the National Apology to the Stolen Generations delivered in 2008 by the then Prime Minister, Kevin Rudd, when it became evident that an Aboriginal and Torres Strait Islander musical renaissance was underway. This was signalled by the release in 2008 of both Geoffrey Gurrumul Yunupingu's self-titled solo album - the first full-length popular music recording sung entirely in an Aboriginal language (Yolngu) - and the first of Jessica Mauboy's outpouring of mainstream pop hits.

Subsequently, music teachers became more aware of, and sensitive towards, protocols and potential restrictions pertaining to the inclusion of certain Indigenous music forms in classroom practice, which was a welcome development. However, many were deterred from programming Aboriginal and Torres Strait Islander music for fear of committing cultural errors (Locke and Prentice 2016). And so, the continuing absence of Indigenous music from classrooms perpetuated a distorted social and cultural understanding of the nation-state and has consequences for both Indigenous and non-Indigenous students to this day. Encountering music of their own cultural heritage in school can affirm Aboriginal and Torres Strait Islander students in their histories and world views and offer comfort and validation (see Boyea 2000, p. 14). And, when handled judiciously, it can beneficially "unsettle" those non-Indigenous students fixed in their own histories and worldviews.

Music educators need to develop confidence and willingness to learn - then teach about how an Aboriginal or Torres Strait Islander politics of identity and survival has been indispensable to Indigenous peoples' resilience and recovery and how music has been crucial to such initiatives. A meaningful first gesture would be for teachers to commit to recognizing the country or local region of every Indigenous musician whose music they bring into the classroom. Many Aboriginal and Torres Strait Islanders "want to be known not just as [Indigenous] Peoples, but by their own distinct inheritance, their unique and separate nations and tribes" (Boyea 1999, p. 46).

The Australian Indigenous musical landscape is more diverse and complex today than it has been at any previous time. This gradual broadening of the music's scope 
has in certain ways enhanced its educative power, by, for example, offering the teacher a broader range of musical repertoire options. In other words, more potential points of entry into the world of Australian Indigenous music now exist. This is helpful for the nonexposed non-Indigenous music teacher who may have "a hard time hearing [Indigenous] music as music, a hard time noticing its complexity, variation, and range of styles, a hard time grasping its principles or organization" (Boyea 1999, 36). It is crucial to have a clear understanding of what comprises contemporary Indigenous music and to be able to discern its intended audiences. These matters have implications for pedagogy, although we are unable to discuss them in detail here. We will however briefly refer to recent innovative classroom work being undertaken in Western Sydney by our colleague Thomas Fienberg (see also Locke and Prentice 2016, pp. 145-148).

\section{Identify, Don't Define}

The Australian Institute of Aboriginal and Torres Strait Islander Studies (AIATSIS) website states that it is better "to identify rather than define Indigenous peoples [...] based on the fundamental criterion of self-identification as underlined in a number of human rights documents". Indigenous music has been seen to include a wide array of "types and styles [...] such as traditional, ethnic, national, regional and folk" and "incorporate[s] song, dance, storytelling, instrumental music, games and drama" (Locke and Prentice 2016, p. 140). It is clear that definitions of what constitutes Indigenous music risk essentializing the music and culture, a situation that educationists have more recently been striving to overcome. As Bracknell has pointed out elsewhere, since both Indigenous and non-Indigenous musicians in Australia now commonly operate within the same broad range of globally established musical style conventions, "it is counterintuitive to cast 'Indigenous music' as a separate genre" (Bracknell 2019, p. 102). For example, country music created and performed by Aboriginal musicians for a worldwide market need not be classified as Aboriginal country music, that is, it need not be marked as an unusual or divergent form of country music. Further, "Indigenous music" as a coverall term is often reliant on "outsider-perceived notions of authenticity and [it] pigeonholes Indigenous artists as exotic" (p. 103). Hence, Bracknell (2019) proposes a baseline description of Indigenous music whereby it is distinguishable both by its "inclusion of musical or lyrical content derived from Indigenous people" (p. 100), and the "Indigenous status of the artists involved in its production" (p. 100).

Bracknell's (2019) approach further clears the way for classroom engagement with the educative power of Aboriginal and Torres Strait Islander music in that it places the music on an equal footing with other music proposed and prescribed by

\footnotetext{
${ }^{5}$ See Indigenous Australians: Aboriginal and Torres Strait Islander people: https://aiatsis.gov.au/ explore/articles/indigenous-australians-aboriginal-and-torres-strait-islander-people.
} 
the syllabus. Hence, an integrative approach to Indigenous music can be taken, whereby its sonic properties can be studied alongside music from any other historical-cultural tradition "to teach concepts, principles, generalizations, and theories" (Howard and Kelley 2018, p. 18). This goes hand in hand with creating opportunities for students to interact and create music with culture bearers, as discussed later in the chapter, "therefore", as one music education text announces optimistically, "debunking the thinking that one cannot understand another culture" (Howard and Kelley 2018, p. 18).

Versions of the NSW syllabus and supporting documents issued in the new millennium allow for this kind of development, although they still do not reflect the most recent developments in Aboriginal and Torres Strait Islander music. For example, for the compulsory topic "Australian Music", the Stages 4 and 5 (Years 7-10) syllabus recommends - in addition to Australian art music "traditional and contemporary music of Aboriginal and Torres Strait Islander peoples within a cultural context" (Board of Studies NSW 2003, p. 37). Here the inference is that Indigenous Australian musicians do not participate in the creation or performance of art music, yet this is a musical context which has evolved rapidly over the past decade, as can heard in the work of such Aboriginal composers as William Barton, Deborah Cheetham and Christopher Sainsbury (see Macarthur 2019, p. 212; Sainsbury 2019). ${ }^{6}$ Neither the Board of Studies (BOS) nor the New South Wales Educational Standards Authority (NESA) which superseded it has brought the documents into line with current musical reality, despite the fact that the Australian Music Centre (AMC) has released a secondary school educational resource kit relating to the developments (AMC n.d.).

The recognition that Aboriginal and Torres Strait Islander music should - or could - be taught "in a cultural context" (Board of Studies NSW 2003, p. 37) opens the way for fuller exploration of the music's educative power. This reflection of the influence of ethnomusicology in music education is a gateway through which Indigenous musicians and community members could - or should - participate in the teaching-learning process, thus pointing to the need for pedagogical expansion. Of the current ideas about Australian Indigenous music and education in circulation, the online Western Australian arts-in-education resource, ArtsEdge, perhaps comes closest to envisioning the music's educative power:
Contemporary Aboriginal music has a multi layered connection to both contemporary Western popular [and now, art] music and to traditional culture, song lines, dreaming, language, country and the spiritual. Like other art forms it has the power to simultaneously transform our understanding of history and culture and to communicate the authentic experience of what it is to be an Indigenous Australian today. (ArtsEdge n.d.)

Contemporary Indigenous music is not merely a hybrid or fusion of Indigenous and non-Indigenous elements but rather a much more nuanced set of musical convergences. Wafer's (2017) important discussion of the traditional-modern

\footnotetext{
${ }^{6}$ See Ngarra-burria: First Peoples Composers in Australia, an Australian Indigenous composers' initiative led by Christopher Sainsbury (Sainsbury n.d.) and Sainsbury (2019).
} 
song continuum is apposite here, which, helpfully and critically for music education, he extends to encompass the entire field of Aboriginal and Torres Strait Islander music making.

\section{Respectful Inclusion}

We began this chapter by referring to the respectful inclusion of Aboriginal and Torres Strait Islander music in teaching and learning schedules. Among ideas that have already been mentioned, respectful inclusion would involve acting upon an understanding that Aboriginal and Torres Strait Islander music is generally created with a specific audience in mind (see Fig. 1). Teachers should bear this in mind when selecting music for study. Graeme Smith explained in a 1991 school music resource booklet:

Though many Aboriginal [popular] musicians perform for and aim to please a general market, they also often feel that they are singing especially for an Aboriginal audience and want to express their ideas to that audience in terms and styles that it understands (p. 82).

Casey (2012) makes this point too, stating, "Contemporary Indigenous theatre [broadly understood] is produced for multiple and various audiences; sometimes for specific and general Indigenous communities, and sometimes for both Indigenous and non-Indigenous communities" (p. 3). Teachers must learn to discern the intended audience for specific items of Indigenous music, as well as the music's key purpose.

Figure 1 conceptualizes the potential audiences and functions of Indigenous music. The most general audience domain, nation-state/world, includes music that

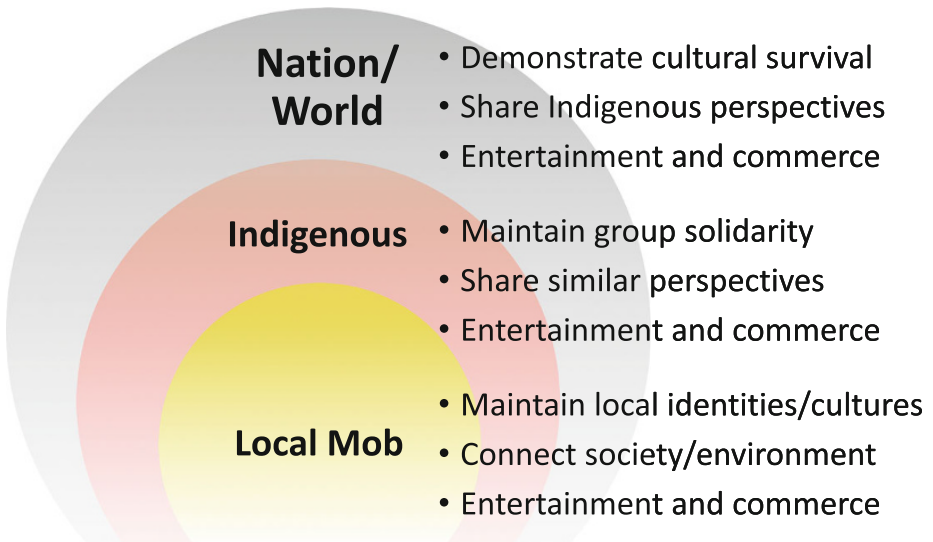

Fig. 1 Schema indicating the nested intended audience(s) for Aboriginal and Torres Strait Islander music, as well as its key function(s) 
communicates Australian Indigenous peoples' perspectives, an informed awareness of which we would consider to be a necessary part of respectful inclusion. Twentyfive years ago, the celebrated Aboriginal musician Archie Roach explained that despite having written songs that dealt with "a lot of things that affected Aboriginal people, [...] I am a separate person from my race.” (p. 139). He continued:

So, a lot of my songs I write now, I'd rather be seen as a singer-songwriter. Because you're an Aboriginal person, people think that you must have a statement or an opinion on everything. I think that slowly they're starting to see the music as being just good music. (Quoted in Coolwell 1993, p. 140)

Here Roach implied that he would rather have his songs considered "good music" than be singled out as "Indigenous". This significant point, that Aboriginal and Torres Strait Islander people have both an individual and a group identity, carries a reminder that educators must guard against essentializing their perspectives.

Aboriginal rock singer Dan Sultan echoed Roach's sentiment two decades later and even wrote a song about it: "No More Explanations" from his 2014 album, Blackbird (Sultan 2014). "As Aboriginal artists", Sultan explained, "we find it hard to just be allowed to be artists" (Watt n.d., n.p.). He is grateful to those popular musicians who came before, since their accomplishments allowed him to explore other topics in his song writing:

It used to be that you had to sing about land rights, you had to sing about children being taken away, which I've done [. . . ] but thanks to No Fixed Address and uncle Archie [Roach] I can just be in a rock'n'roll band. I don't have to be a martyr.' (Mathieson 2014, n.p.)

Indeed, the lyrical content in much of the music by contemporary Aboriginal and Torres Strait Islander musicians such as Sultan, Jessica Mauboy, Busby Marou and Thelma Plum addresses themes common in global pop and rock music.

The 2017 song "In Between" by the Aboriginal duo, Apakatjah, from Central Australia was composed with the intention of maintaining Indigenous group solidarity through shared experience and perspectives, as illustrated by the middle "Indigenous" domain in Fig. 1. The lyrics of its first chorus contain the lines, "In a world that sees just black and white/What about me, where is it I fit in?" (Apakatjah 2017). The 2018 rap song "My People" by Aboriginal musician J-Milla (Jacob Nichaloff) opens with these lines: "People forget that I'm half white/But now, I'm speaking out for my black side" (J-Milla 2019). These songs - and others like them pick up where rock band Coloured Stone's 1984 hit "Black Boy" left off, with its message of pride in one's cultural heritage (Coloured Stone 1997). They also thematically echo the mid-twentieth century country song "Outcast Halfcaste" recently revived by Emma Donovan and Jessie Lloyd (Mission Songs Project 2017). Like "Black Boy" and "Outcast Halfcaste", "In Between" and "My People" primarily address Indigenous people who might identify with their lyrical exploration of Indigenous identity and belonging. 
At the most specific level is music created by and for a Local Mob, ${ }^{7}$ which may or may not be restricted in audience terms to members of that community. In parts of the country where Aboriginal "land-based cosmologies have survived down to the present day", the related singing practices that form part of an "unbroken tradition" may be specifically intended for a very particular local audience (Wafer 2017, p. 5). Still, one Aboriginal traveling song known by various names including "Wanji Wanji" was performed throughout the last century across half of the continent (Turpin et al. 2019).

Discerning the intended audience for a particular piece of music could, and in many cases should, involve consulting with representatives of Aboriginal or Torres Strait Islander communities. Students in our university class have successfully contacted musicians through social media, by which means they have gained insights into song meanings and have secured permission to perform certain songs. Music created for nation-state/world audiences is generally well suited for school study, although since each domain includes music that is commercially available, educators could explore such music for its educational potential as well.

\section{A Pedagogy of Partnership}

Dialogue between Indigenous and non-Indigenous music educators is of paramount importance when developing curricula involving Aboriginal and Torres Strait Islander music. Since the new millennium "non-Indigenous composers have engaged in collaborative projects with Indigenous musicians" (Macarthur 2019, p. 212), resulting in works such as Paul Stanhope's 2014 dramatic cantata, Jandamarra: Sing for the Country. For a number of years our colleague Thomas Fienberg has been developing and trialling new approaches to teaching Indigenous music derived from his study of such collaborative performance and composition processes. His $\mathrm{PhD}$ study tracked over several years the attitudes and levels of engagement of a cohort of non-Indigenous Sydney secondary school elective music students of diverse cultural backgrounds as he taught them about Aboriginal and Torres Strait Islander music (Fienberg 2019a). The students' learning culminated in a project that involved the "collaborative reworking of two songs that had been shared with the class by Ngiyampaa composer and dancer Peter Williams" (Fienberg 2019a, p. iii).

Since 2017, Fienberg has participated in an ongoing school-based artistic outreach programme that "make[s] space for Indigenous voices to guide instruction and share knowledge" (Fienberg 2019b, n.p.). His recent working processes can be glimpsed in a video produced in 2020 as part of an artist-in-residence programme run at the Western Sydney secondary school where he teaches, which involved the

\footnotetext{
${ }^{7}$ The Aboriginal term "mob" is an English loan word that refers to a cohesive group such as a specific extended family, or more broadly, a linguistic community.
} 


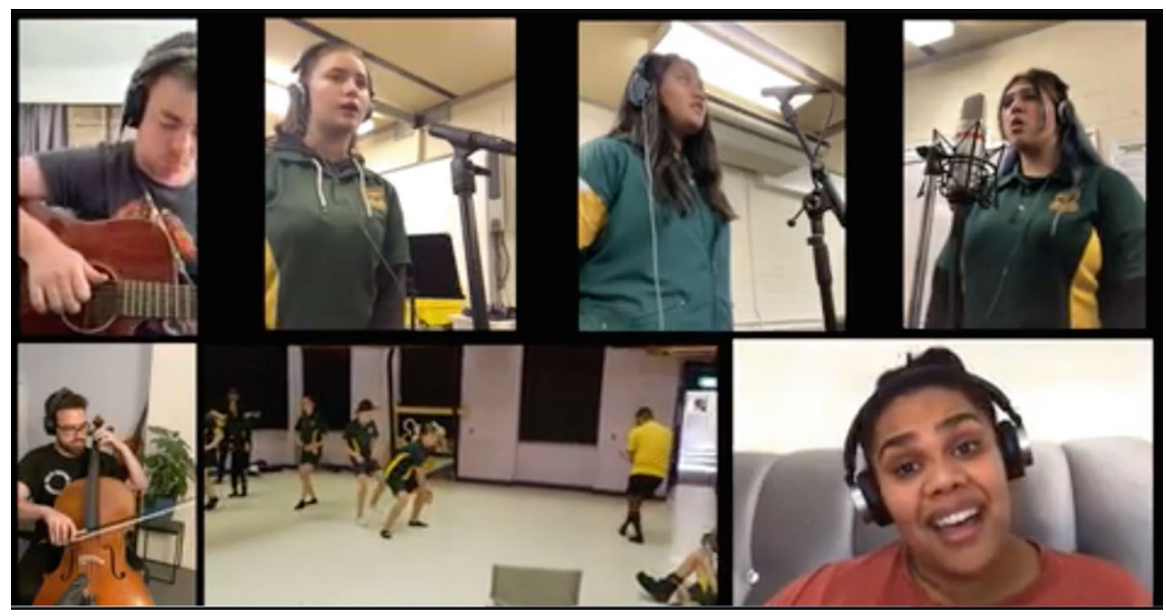

Fig. 2 Screenshot from the "Bapa" collaborative performance video involving student singers and dancers, Evie J. Willie (bottom right), Neville Williams-Boney (bottom centre) and teacher instrumentalists. (Source: NSW Department of Education 2020b, Used with permission of the NSW Department of Education)

Wiradjuri/Ni-Vanuatu singer Evie J. Willie (NSW Department of Education 2020a). With Fienberg himself on guitar and a fellow teacher on double bass, Willie and several students perform the song "Bapa" by the late Geoffrey Gurrumul, singing in the Yolngu language of the Northern Territory. The Wiradjuri dancer-choreographer Neville Williams-Boney created dance movements inspired by the song lyrics, excerpts of which can be seen being rehearsed in an inset in the video (Fig. 2). Not only is the approach collaborative and culturally inclusive; it also reunites song and dance in ways previously untried in the suburban school setting.

Such projects have the potential for expansion and broader application and indicate the educative power of Indigenous music and dance forms and practices, where the cultural aspects of language, song, dance and story can be explored from various mutually enriching perspectives. As Boyea (1999) convincingly argues, in the classroom, Indigenous music "provides, more powerfully than other media, opportunity for [non-Indigenous people] to sense the depth and power and intensity of [Indigenous] life, to experience its difference, and yet to feel a closeness to [Indigenous] ways that cannot be spoken, fully understood, or retained" (p. 36).

\section{Conclusion}

In this chapter we have argued for the full, respectful curricular inclusion of Aboriginal and Torres Strait Islander music, in order to promote in schools a more balanced and equitable social and cultural vision of the nation-state. Strategies we have proposed towards this end include avoiding making a binary distinction 
between traditional and contemporary music, learning to discern the intended audience for specific items of Indigenous music as well as the music's key purpose and guarding against essentializing Indigenous perspectives - the first step being to acknowledge the country of musicians studied, out of an awareness of Indigenous linguistic and cultural diversity.

A hopeful sign of changing attitudes in Australian society and musical culture is the recent upsurge in collaborations between non-Indigenous and Indigenous musicians. "The Campfire Song" by Kasey Chambers (2018) featuring Yawuru elder and musician Alan Pigram, "Someone" by William Crighton (2018) featuring Arnhem Land singer Stanley Gawurra Gaykamangu and Jaara Nyilamum by Yorta/Dja Wurrung composer Lou Bennett AM (2020) with the Australian String Quartet are but three recent examples of a trend that relates to aspects of Australia's often troubled national politics of reconciliation between Indigenous and non-Indigenous people. As we have shown, these kinds of inclusionary musical expressions point to the potential of pedagogies involving partnership.

By drawing on the notion of educative power, it has been our intention to encourage - empower even - teachers of all backgrounds to explore ways to respectfully incorporate Aboriginal and Torres Strait Islander music in their teaching repertoires and place it on an equal footing with other music they teach. Given the considerable diversity of Indigenous musical expressions now readily accessible, they can employ familiar musical-technical approaches even as they begin to more fully investigate the music's cultural-contextual meanings. The latter will entail consultation and partnership with Aboriginal and Torres Strait Islander cultural representatives - musicians, community members and Indigenous fellow teachers. This will help clear the way for the classroom to become an environment in which students can glimpse the vitality of contemporary Australian Indigenous musical expressions.

\section{References}

AMC (Australian Music Centre). (n.d.). Ngarra Burria: Part 1. Digital educational resource kit. http://echo.australianmusiccentre.com.au/\#lm-9. Accessed 17 Jul 2020.

Apakatjah. (2017). In between. On In between [CD]. Australia: CAAMA Music.

Bennett, L. (2020). Jarra Nyilamum [recorded by Lou Bennett and the Australian String Quartet]. On Australian Anthology [Digital album]. Australia: Dr Lou Bennett AM and Australian String Quartet.

Board of Studies NSW. (2003). Music years 7-10 syllabus. Sydney: Board of Studies NSW.

Board of Studies NSW. (2004). Music years 7-10 syllabus advice on programming and assessment. Sydney: Board of Studies NSW.

Boyea, A. (1999). Encountering complexity: Native musics in the curriculum. Philosophy of Music Education Review, 7(1), 31-48.

Boyea, A. (2000). Teaching native American music with story for multicultural ends. Philosophy of Music Education Review, 8(1), 14-23.

Bracknell, C. (2019). Identity, language and collaboration in Indigenous music. In L. Bamblett, F. Myers, \& T. Rowse (Eds.), The difference identity makes: Indigenous cultural capital in Australian cultural fields (pp. 99-123). Canberra: Aboriginal Studies Press. 
Breen, M. (2007/1989). Preface. In M. Breen (Ed.), Our place, our music: Aboriginal music, Australian popular music in perspective volume 2 (pp. xi-xii). Canberra: Aboriginal Studies Press.

Casey, M. (2012). Telling stories: Aboriginal Australian and Torres Strait Islander performance. North Melbourne: Australian Scholarly.

Casey, B. (2018). "Sun Arise": The appropriation of Australia's First Peoples' music, 1956-1974. Journal of Australian Studies, 42(3), 357-373.

Chadwick, G., \& Rrurrambu, G. (2004). Music education in remote Aboriginal communities. The Asia-Pacific Journal of Anthropology, 5(2), 159-171.

Chambers, K. (2018). The campfire song [recorded by Kasey Chambers and The Fireside Disciples featuring Alan Pigram]. On Campfire [CD]. Australia: Warner Music.

Clough, B. (2012). Oceanic reggae. In C. Cooper (Ed.), Global reggae (pp. 265-283). Jamaica: Canoe Press.

Coloured Stone. (1997). Black boy. On Bunna Lawrie's best of Coloured Stone Vol. 1 [CD]. Australia: CAAMA Music.

Coolwell, W. (1993). My kind of people: Achievement, identity and Aboriginality. St Lucia: University of Queensland Press.

Corn, A. (2017, September 14). My favourite album: Yothu Yindi's Tribal Voice. The Conversation. https://theconversation.com/my-favourite-album-yothu-yindis-tribal-voice-83643. Accessed $16 \mathrm{Jul}$ 2020.

Crighton, W. (2018). Someone [recorded by William Crighton featuring Stanley Gawurra Gaykamangu]. On Empire [CD]. Australia: Australian Broadcasting Corporation.

Ellis, C. J. (1974). Music education and Aboriginal performers. The Australian Journal of Indigenous Education, 14, 25-26.

Ellis, C. J. (1984). The nature of Australian Aboriginal music. International Journal of Music Education, 4(1), 47-50.

Fienberg, T. (2019a). Collaboration, community and co-composition: A music educator's ethnographic account of learning (through and from) Aboriginal and Torres Strait Islander music. $\mathrm{PhD}$ Thesis, The University of Sydney.

Fienberg, T. (2019b). Finding Solid Ground: Industry collaboration and mentoring Aboriginal and Torres Strait Islander students in Australian schools. Paper presented at the 14th Cultural Diversity in Music Education International Conference, Tel Aviv, Israel 16-19 June 2019. https://cdime2019.levinsky.ac.il/wp-content/uploads/sites/16/2019/05/Finding-Solid-GroundSunday-16.pdf. Accessed 17 Jul 2020.

Giese, H. (n.d.). Webpage. http://www.harrychristiangiese.com.au/culture.html. Accessed 9 Dec 2019.

Guy, S. (2015). Bodies, myth, and music: How contemporary Indigenous music contesting a mythologized Australian nationalism. eSharp 23, 1-21. Online: http://www.gla.ac.uk/media/ media_404383_en.pdf. Accessed 17 Jul 2020.

Haebich, A. (2018). Dancing in the shadows: Histories of Nyungar performance. Crawley: UWA Publishing.

Harris, A. (2017, April 6). Dreamtime to Aboriginal theatre: Representations of Indigenous music and dance. Talk given at the national Library of Australia. https://www.nla.gov.au/audio/ dreamtime-to-aboriginal-theatre. Accessed 17 Jul 2020.

Howard, K., \& Kelley, J. (2018). World music pedagogy: Secondary school innovations (Vol. 3). New York: Routledge.

J-Milla. (2019). My people [digital]. Australia: Black and Deadly Records.

Kartomi, M. J. (1988). 'Forty-thousand years': Koori music and Australian music education. Australian Journal of Music Education, 1(special issue), 11-28.

Keating, P. (1992). Transcript of Redfern Park Speech (Year of the World's Indigenous People) delivered on 10 December. https://antar.org.au/sites/default/files/paul_keating_speech_tran script.pdf. Accessed 17 Jul 2020. 
Kleinert, S. (2010). Aboriginal enterprises: Negotiating an urban Aboriginality. Aboriginal History, 34, 171-196.

Locke, T., \& Prentice, L. (2016). Facing the Indigenous 'other': Culturally responsive research and pedagogy in music education. The Australian Journal of Indigenous Education, 45(2), 139-151.

Macarthur, S. (2019). Seeking the Indigenous dimensions of the Australian classical music field. In L. Bamblett, F. Myers, \& T. Rowse (Eds.), The difference identity makes: Indigenous cultural capital in Australian cultural fields (pp. 200-215). Canberra: Aboriginal Studies Press.

Mathieson, C. (2014). Dan Sultan: The music of back and forth. SMH. https://www.smh.com.au/ entertainment/music/dan-sultan-the-music-of-back-and-forth-20140403-361d5.html. Accessed 17 Jul 2020.

Mission Songs Project. (2017). The songs back home. CD recording MP002. http:// missionsongsproject.com/

Moyle, A. (1981). Classroom studies in Aboriginal music and dance. The Australian Journal of Music Education, 29, 17-20.

Moyle, A. (2019). MS 3501 Alice Moyle Collection: Finding aid. Australian Institute of Aboriginal and Torres Strait Islander Studies. https:/aiatsis.gov.au/sites/default/files/catalogue_resources/ ms3501_moyle.pdf. Accessed 17 Jul 2020.

Neuenfeldt, K. (1997, February). Indigenous popular music: An example of cultural vitality and a curriculum resource. Counterpoint, 42-46.

NSW Department of Education. (2020a, June 3). Student musical tribute to Dr G. https://education. nsw.gov.au/news/latest-news/student-musical-tribute-to-dr-g. Accessed 17 Jul 2020.

NSW Department of Education. (2020b, June 3). Evans High School Solid Ground Artist in Residence Program 'Bapa' Dr G Yunupingu. Video, 2:47. https:/education.nsw.gov.au/news/ latest-news/student-musical-tribute-to-dr-g. Accessed 17 Jul 2020.

Ottosson, A. (2015). Making Aboriginal men and music in Central Australia. New York: Bloomsbury Academic.

Rowse, T. (2017). Indigenous and other Australians since 1901. Sydney: UNSW Press.

Sainsbury, C. (2019). Platform Papers 59: Ngarra-Burria: New music and the search for an Australian sound. Sydney: Currency Press.

Sainsbury, C. (n.d.). Ngarra-Burria. http://www.sainsburymusic.com/ngarra-burria. Accessed 17 Jul 2020.

Secondary Schools Board. (1983). Music syllabus years 8-10. Sydney: D. West, Government Printer.

Smith, G. (1991). Australian popular music. Sydney: Australian Music Centre.

Smith, G. (2009). Public multicultural music and the Australian state. Music \& Politics, 3(2), 1-14. https://quod.lib.umich.edu/m/mp/9460447.0003.202/\%2D\%2Dpublic-multicultural-musicand-the-australian-state?rgn=main;view=fulltext. Accessed 17 Jul 2020.

Taylor, T. (2007). Beyond exoticism: Western music and the world. Durham: Duke University Press.

Turpin, M., Croft, B., Bracknell, C., \& Meakins, F. (2019). Aboriginal Australia's smash hit that went viral. The Conversation. https://theconversation.com/aboriginal-australias-smash-hit-thatwent-viral-112615. Accessed 17 Jul 2020.

Wafer, J. (2017). Introduction: Everything got a song. In J. Wafer \& M. Turpin (Eds.), Recirculating songs: Revitalising the singing practices of Indigenous Australia (pp. 1-44). Canberra: Asia-Pacific Linguistics.

Watt, D. (n.d.). Dan Sultan. The Beat. https://www.beat.com.au/dan-sultan-2/. Accessed 17 Jul 2020 . 
Michael Webb lectures in music education and ethnomusicology at the Sydney Conservatorium of Music, The University of Sydney, where he is an Associate Professor. He specializes in historical and contemporary music of Melanesia and recently created for online delivery the unit of study, Australian Indigenous Music.

Clint Bracknell is a Noongar musician and researcher from the south coast region of Western Australia and Associate Professor at Edith Cowan University. He writes, performs and produces music for stage and screen while leading a programme of research on enhancing connections between song, language, culture and nature.

Open Access This chapter is licensed under the terms of the Creative Commons Attribution 4.0 International License (http://creativecommons.org/licenses/by/4.0/), which permits use, sharing, adaptation, distribution and reproduction in any medium or format, as long as you give appropriate credit to the original author(s) and the source, provide a link to the Creative Commons license and indicate if changes were made.

The images or other third party material in this chapter are included in the chapter's Creative Commons license, unless indicated otherwise in a credit line to the material. If material is not included in the chapter's Creative Commons license and your intended use is not permitted by statutory regulation or exceeds the permitted use, you will need to obtain permission directly from the copyright holder.

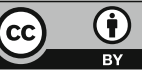

